\title{
Characterization and PCR detection of hepatopancreatic parvovirus (HPV) from Penaeus monodon in Thailand
}

\author{
Wasana Sukhumsirichart ${ }^{1}$, Chainarong Wongteerasupaya ${ }^{4}$, Vichai Boonsaeng ${ }^{1, *}$, \\ Sakol Panyim ${ }^{1}$, Siriporn Sriurairatana ${ }^{5}$, Boonsirm Withyachumnarnkul ${ }^{2}$, T. W. Flegel $^{3}$ \\ ${ }^{1}$ Dept. Biochemistry, ${ }^{2}$ Dept. Anatomy, ${ }^{3}$ Dept. Biotechnology, Faculty of Science, Mahidol University, Rama VI Road, \\ Bangkok 10400, Thailand \\ ${ }^{4}$ Dept. Biochemistry, Faculty of Medicine, Srinakharinwirot University, Sukhumvit 23, Bangkok 10110, Thailand \\ ${ }^{5}$ Dept. Pathology, Faculty of Medicine, Ramathibodi Hospital, Mahidol University, Rama VI Road, Bangkok 10400, Thailand
}

\begin{abstract}
Hepatopancreatic parvovirus (HPV) causes disease in several species of penaeid shrimp. Heavy infections may result in poor growth and reduced production for shrimp farmers. From one southern Thai shrimp pond with a high prevalence of HPV infection, 790 shrimp were sampled randomly and the hepatopancreas (HP) removed. Most HP were preserved in liquid nitrogen. However, every 10th HP ( 79 total) was divided into 2 parts appropriately fixed for examination by transmission electron microscopy (TEM) and light microscopy. Based on light microscopy, the prevalence of HPV infection in the pond was approximately $30 \%$ and its presence was confirmed by TEM of parallel samples. The virus was subsequently purified from hepatopancreatic homogenates of the samples preserved in liquid nitrogen. Negative staining of the purified viral preparation revealed unenveloped, icosahedral viral particles 22 to $24 \mathrm{~nm}$ in diameter. Agarose gel electrophoresis of nucleic acid extracts revealed the presence of 2 fragments, one very intense $(5.8 \mathrm{~kb})$ and the other weak $(4.2 \mathrm{~kb})$. The larger fragment was degraded by DNase I and $\mathrm{S}_{1}$ nuclease, indicating single-stranded DNA (ssDNA) characteristic of the viral family Parvoviridae. The smaller fragment was degraded by DNase I but not by $\mathrm{S}_{1}$ nuclease, indicating that it comprised double-stranded DNA. A genomic DNA library of the $5.8 \mathrm{~kb}$ ssDNA was constructed in pUC18 and a clone containing a $659 \mathrm{bp}$ fragment specific and sensitive for HPV was selected for sequencing. Based on this sequence, an HPV-specific primer set was designed to yield a $156 \mathrm{bp}$ amplicon by polymerase chain reaction (PCR) amplification. The expected $156 \mathrm{bp}$ amplicon was obtained only in the presence of HPV DNA template (at as little as $1 \mathrm{fg}$ purified DNA) and not with nucleic acid templates extracted from healthy shrimp tissue or other shrimp pathogens. It is hoped that this PCR assay will be useful to shrimp aquaculturists for early detection and screening of shrimp larvae, parental broodstock or other possible carriers of HPV in the shrimp cultivation system.
\end{abstract}

KEY WORDS: Hepatopancreatic parvovirus (HPV) - Polymerase chain reaction - Penaeus monodon

\section{INTRODUCTION}

Hepatopancreatic parvovirus (HPV) infects several penaeid shrimp species and is widely distributed in many parts of the world (Lightner 1996). In Thailand, HPV in the black tiger shrimp Penaeus monodon was first reported in 1992 (Flegel et al. 1992a, Flegel \& Sriurairatana 1993, 1994) and it is currently being stud-

•Addressee for correspondence. E-mail: scvbs@mahidol.ac.th ied to determine whether it has any economic impact on the shrimp culture industry. Shrimp infected with HPV usually show non-specific gross signs of disease, but there is anecdotal information suggesting that heavy infections can cause poor growth. In earlier publications based on preliminary data (Flegel et al. 1992b, 1995, Flegel 1997), it was suggested that the percentage of HPV-infected larvae at pond stocking would roughly equate to the minimum mortality to expect for that pond. For example, it was suggested 
that a rate of $50 \%$ HPV infection in the stocked postlarvae would lead to a maximum survival of $50 \%$. This was based on survivals calculated from cast net samples and samples of harvested shrimp. However, there are now indications that the shrimp do not actually die but grow so slowly that they escape the cast net and harvest net samples (Flegel et al. 1999). In spite of this, the economic consequence for the farmer is the same as death. High levels of HPV infection have been reported, especially in early juvenile stages (Flegel et al. 1995, Lightner 1996), but the economic impact has not been clearly established.

The normal diagnostic methods to detect HPV infection include routine histological methods and transmission electron microscopy (TEM) (Lightner 1996). Both methods provide reliable results but need specialists and equipped laboratories and this limits their field application. A test described for Giemsa-stained hepatopancreatic tissue impression smears is rapid and suitable for field study, but the sensitivity and accuracy of detection is low (Lightner et al. 1993, Lightner 1996). All of these tests also suffer the disadvantage of being destructive. A gene probe assay developed from a Korean strain of HPV in Penaeus chinensis has been described (Bonami et al. 1995). This provides for sensitive detection of the South Korean HPV isolate in $P$. chinensis (HPV-chin), but it does not react with HPV present in Macrobrachium rosenbergii from Malaysia. This suggests that different species or strains of HPV may exist in different species of shrimp (Lightner et al. 1994).

Polymerase chain reaction (PCR) technology has been proven as a powerful diagnostic tool for shrimp viral infections and for detection of viral reservoirs in carrier species. Examples where it has been used include the white-spot syndrome virus complex (WSSV) (Kimura et al. 1996, Lo et al. 1996, Takahashi et al. 1996, Kanchanaphum et al. 1998), Baculovirus penaei (BP) (Wang et al. 1996) and yellow-head virus (YHV) (Wongteerasupaya et al. 1997). Therefore, this study was carried out to characterize HPV from Penaeus monodon in Thailand (HPV-mon) and to develop a rapid, simple, specific and sensitive method for its detection using a PCR-based assay.

\section{MATERIALS AND METHODS}

Chemicals and reagents. DNase $I$ and nuclease $S_{1}$ were purchased from Sigma Chemical Co (St. Louis, MO, USA). Restriction enzymes Sau 3AI and Bam HI, and molecular size markers were obtained from BRL (Bethesda Research Laboratories, Gaithersburg, MD, USA). T4 DNA ligase, DNA polymerase large (Klenow) fragment, and deoxynucleotide triphosphate (dNTP) were obtained from New England Biolabs, Taq DNA polymerase was from Perkin-Elmer Cetus. Kits for digoxigenin labeling of DNA for use in dot blot, Southern blot and in situ hybridization assays were purchased from Boehringer Mannheim Co. Ltd and assays were carried out as described in the manual accompanying the kits. DNA probes derived from the Korean isolate of hepatopancreatic parvovirus (HPV-chin) and infectious hematopoietic and hypodermal necrosis virus (IHHNV) were obtained from DiagXotics Inc. (Wilton, CT, USA).

Shrimp specimens. In 1995, one shrimp pond from southern Thailand was found to have a high prevalence of HPV infection based on characteristic histology in sampled shrimp. Shrimp (790) were subsequently sampled randomly from this pond for histological examination by light microscopy and TEM and for viral purification. Shrimp were stunned in an ice bath and then the hepatopancreases were removed and transferred immediately to liquid nitrogen in 4 lots of approximately 200 each for subsequent storage at $-80^{\circ} \mathrm{C}$ until used for viral purification. During processing, the hepatopancreas from every tenth specimen (total 79) was divided into 2 sub-sample parts, one small portion fixed for TEM and the other larger portion fixed for light microscopy. The latter samples were used to estimate the prevalence of HPV infection in the pond and TEM was used to verify the HPV diagnosis by light microscopy.

Histology and ultrastructure. Portions of hepatopancreatic tissues were fixed in Davidson's fixative and processed for normal histology as described by Bell \& Lightner (1988). For TEM of thin sections, tissues were fixed in $4 \%$ paraformaldehyde plus $1 \%$ glutaraldehyde in $0.1 \mathrm{M}$ phosphate buffer $\mathrm{pH} \mathrm{7}$, and processed as previously described (Fegan et al. 1991). During viral purification, centrifugal fractions were negatively stained on formvar coated copper grids using $0.5 \%$ sodium phosphotungstate (Sigma Chemical Co.). All samples were examined using a Hitachi H-7100 transmission electron microscope.

Viral purification. The method for HPV purification was modified from the procedures previously described by Wongteerasupaya et al. (1995a) and Bonami et al. (1995). Briefly, about 40 frozen hepatopancreases were thawed and homogenized in NaCl-Tris-EDTA (NTE) buffer $(0.2 \mathrm{M} \mathrm{NaCl}, 0.02 \mathrm{M}$ Tris-HCl, $\mathrm{pH} 7.4$, $0.02 \mathrm{M}$ EDTA), followed by centrifugation on a Sorvall $\mathrm{RC} 28 \mathrm{~S}$ centrifuge twice at 5473 and $18878 \times \mathrm{g}$ for $15 \mathrm{~min}$ each at $4^{\circ} \mathrm{C}$ to remove cellular debris. Supernatant fluid was subsequently centrifuged at $140000 \times$ $g$ at $4^{\circ} \mathrm{C}$ for $3 \mathrm{~h}$ on a Beckman LB $70 \mathrm{M}$ ultra-centrifuge (sw 40 Ti rotor). The supernatant was then discarded and the pellet was gently resuspended in $1 \mathrm{ml} \mathrm{NTE}$ buffer at $4{ }^{\circ} \mathrm{C}$. The suspension was layered onto the top 
of a continuous gradient of 15 to $40 \%$ urografin and centrifuged again at $140000 \times g$ for $2 \mathrm{~h} 45 \mathrm{~min}$ at $4^{\circ} \mathrm{C}$. Fractions were removed using a Pasteur pipette and diluted in NTE buffer to give a final volume of $12 \mathrm{ml}$, before they were again centrifuged at $140000 \times g$ for $3 \mathrm{~h} 30 \mathrm{~min}$ at $4^{\circ} \mathrm{C}$. The pellets were resuspended in $1 \mathrm{ml}$ TE buffer (10 mM Tris- $\mathrm{HCl}, \mathrm{pH} 7.4$ and $1 \mathrm{mM}$ EDTA) and examined for the presence of viral particles by negative staining using TEM. Samples containing viral particles were stored at $-80^{\circ} \mathrm{C}$ until used.

Nucleic acid isolation and characterization. A stored viral suspension determined by TEM to contain purified viral particles was thawed and treated with $50 \mu \mathrm{g} \mathrm{ml}^{-1}$ proteinase $\mathrm{K}$ for $30 \mathrm{~min}$ at $37^{\circ} \mathrm{C}$. This was followed by $0.5 \%$ sarkosyl treatment for $1 \mathrm{~h}$ at $65^{\circ} \mathrm{C}$ (Bonami et al. 1990). The viral nucleic acid was then extracted with phenol and chloroform-isoamyl alcohol $(24: 1: 1 \mathrm{v} / \mathrm{v})$ and precipitated with absolute ethanol. The DNA pellet was washed with $70 \%$ ethanol, airdried and resuspended in TE buffer. The purified HPV nucleic acid was analyzed by agarose gel electrophoresis. The bands appearing on the gel were subsequently excised individually and recovered using electroelution (Hoefer, Hoefer Scientific Instruments). The DNA solution $(100 \mu \mathrm{l})$ from each band was collected in separate microcentrifuge tubes. The DNA was precipitated using absolute ethanol and then resuspended in TE buffer. The concentration of DNA in each tube (i.e. from each band) was then estimated spectroscopically and adjusted to be similar. Fractions of these DNA samples, control DNA, ssDNA of M13 (Biolabs; New England Biolabs, Inc.) and $\lambda$-Hind III DNA were then treated separately with 0.01 units of nuclease $\mathrm{S}_{1}$ and $100 \mu \mathrm{g} \mathrm{ml}^{-1} \mathrm{DNase} \mathrm{I}$ at $37^{\circ} \mathrm{C}$ for $30 \mathrm{~min}$ before electrophoresis on a $0.7 \%$ agarose gel.

Preparation of double-stranded DNA (dsDNA). In order to obtain enough dsDNA for cloning, the total genomic DNA of HPV was used as a template for the synthesis of complementary stranded DNA using DNA polymerase I (Klenow fragment). The $20 \mu \mathrm{l}$ reaction mixture modified from Wongteerasupaya et al. (1997) contained $2.5 \mu \mathrm{M}$ random hexamer (Pharmacia), $1 \mathrm{mM}$ each of deoxynucleotide triphosphate (dNTP), $50 \mathrm{mM}$ Tris- $\mathrm{HCl}, \mathrm{pH} 8.3,10 \mathrm{mM} \mathrm{MgCl}_{2}, 5 \mathrm{mM} \mathrm{NaCl}$, and DNA template. The DNA amplification was performed in a DNA thermal cycler 480 (Perkin-Elmer Cetus) using the following thermal protocol: $1 \mathrm{~min}$ denaturation at $95^{\circ} \mathrm{C}, 3 \mathrm{~min}$ annealing at $20^{\circ} \mathrm{C}$, and 5 min extension at $37^{\circ} \mathrm{C}$ for 8 cycles with the addition of 2 units of Klenow polymerase at each annealing step.

Cloning and screening for HPV-specific DNA fragments. The dsDNA prepared from HPV was digested with Sau $3 \mathrm{AI}$ and ligated to Bam HI-digested pUC18 using $\mathrm{T}_{4}$ DNA ligase. The recombinant plasmids were then introduced into Escherichia coli JM 109 and transformants were screened on LB-agar containing $100 \mu \mathrm{g} \mathrm{ml}^{-1}$ ampicillin, $1 \mathrm{mM}$, isopropyl-D-thiogalactopyranoside (IPTG) and 2\% 5-bromo-4-chloro-3-indoylgalactoside (X-gal). White colonies were selected and plasmid DNA was isolated by the alkaline lysis method (Maniatis et al. 1982). Inserted DNA fragments were excised from recombinant plasmids by double digestion with Eco RI and Pst I followed by electrophoresis on $0.7 \%$ agarose gels. The resulting bands were transferred to a nylon membrane and hybridized with digoxigenin-labeled HPV genomic DNA. Fragments that strongly hybridized with HPV DNA were selected. They were labeled with digoxigenin and used as probes for dot blot hybridization with genomic DNA from HPV, WSSV, Salmonella and shrimp and with RNA from YHV. An HPV-specific DNA fragment of 659 bp (pMUH659) which hybridized only to HPV DNA was selected for further study.

Probe labeling. HPV-specific DNA fragments of 659 and $156 \mathrm{bp}$ were labeled with dUTP-digoxigenin by random prime and specific prime methods, respectively, using digoxigenin labeling kits (Boehringer Mannheim).

Alkaline gel electrophoresis. A denaturing alkaline agarose gel $(0.7 \% \mathrm{w} / \mathrm{v})$ was prepared (Maniatis et al. 1982). The DNA samples were mixed with EDTA (10 $\mathrm{mM}$ final concentration) and $6 \times$ alkaline loading buffer $(300 \mathrm{mM} \mathrm{NaOH}, 6 \mathrm{mM}$ EDTA, 30\% glycerol, $0.15 \%$ bromocresol green, $0.25 \%$ xylene cyanol FF) and then loaded into the well. Electrophoresis was carried out at $10 \mathrm{~V}\left(0.25 \mathrm{~V} \mathrm{~cm}^{-1}\right)$ overnight.

Southern blot hybridization. HPV genomic DNA was examined by Southern blot hybridization in 2 ways. In one set, an alkaline transfer was used to denature the DNA; in the other, no alkali was used (Maniatis et al. 1982). The DNA was transferred onto a nylon membrane using a vacuum blotting system (Pharmacia) and then hybridized with digoxigenin-labeled inserted fragments $(659 \mathrm{bp})$ of the selected recombinant plasmid, pMUH659.

In situ hybridization. The method for in situ hybridization was carried out as recommended in the Boehringer Mannheim Genius kit manual with the following modification. Tissue sections on slides were treated with 20 to $30 \mu \mathrm{l}$ proteinase $\mathrm{K}\left(10 \mu \mathrm{g} \mathrm{ml}^{-1}\right.$ of proteinase $\mathrm{K}, 50 \mathrm{mM}$ Tris- $\mathrm{HCl}, \mathrm{pH} 7.4,10 \mathrm{mM}$ EDTA and $10 \mathrm{mM} \mathrm{NaCl}$ ) for $15 \mathrm{~min}$ at $37^{\circ} \mathrm{C}$. The sections were then treated with $0.4 \%$ formaldehyde for $5 \mathrm{~min}$ at $4{ }^{\circ} \mathrm{C}$ to stop proteinase $\mathrm{K}$ activity, then immersed in distilled water for $5 \mathrm{~min}$. After air drying, the sections were treated with 15 to $20 \mu \mathrm{l}$ of probe cocktail (50\% formamide, $5 \times \mathrm{SSC}, 200 \mu \mathrm{g} \mathrm{ml}^{-1}$ sonicated salmon sperm DNA, $10 \%$ dextran sulfate, $1 \times$ Denhardt's solution and $10 \mathrm{ng} \mathrm{ml}^{-1}$ labeled probe). The slides were heated at $95^{\circ} \mathrm{C}$ for $6 \mathrm{~min}$, cooled on ice and then placed in a humid chamber overnight. They were then washed 
twice with $2 \times \mathrm{SSC}$ for $5 \mathrm{~min}$ and once with $0.1 \times \mathrm{SSC}$ at $42^{\circ} \mathrm{C}$ for $10 \mathrm{~min}$. The detection of hybrids was performed as described in the manual. The slides were counterstained for a few seconds with $0.5 \%$ Bismarck brown before being dehydrated and mounted with Permount (Fisher Scientific).

DNA sequences and PCR primer design. The nucleotide sequence of pMUH659 was determined using an ABI PRISM 377 automated sequencer and nucleotide primers were designed using oligo 4.0s computer software. The primer sets $121 \mathrm{~F}\left(5^{\prime}\right.$..GCA CTT ATC ACT GTC TCT AC..3') and 276R (5'..GTG AAC TTT GTA AAT ACC TTG..3') were selected for use in a PCR assay.

PCR amplification. DNA was amplified by PCR in a $50 \mu$ reaction mixture containing DNA templates, $1 \times$ $\mathrm{PCR}$ reaction buffer $(10 \mathrm{mM}$ Tris $-\mathrm{HCl}, \mathrm{pH} 8.3,50 \mathrm{mM}$ $\mathrm{KCl}, 0.01 \%$ [w/v] gelatin), $1.5 \mathrm{mM} \mathrm{MgCl}_{2}, 200 \mu \mathrm{M}$ each of dATP, dTTP, dGTP and dCTP, $0.1 \mu \mathrm{M}$ each of primers $(121 \mathrm{~F}$ and $276 \mathrm{R})$ and 2 units of Taq DNA polymerase. The PCR was carried out for 40 cycles of an optimal thermal profile: $30 \mathrm{~s}$ (3 $\mathrm{min}$ for the $1 \mathrm{st}$ cycle) denaturation at $94^{\circ} \mathrm{C}, 30 \mathrm{~s}$ annealing at $52^{\circ} \mathrm{C}$, and $30 \mathrm{~s}$ extension at $72^{\circ} \mathrm{C}$ ( $5 \mathrm{~min}$ for the last cycle). Control reactions containing no template DNA were performed for each PCR reaction. An aliquot of $15 \mu \mathrm{l}$ from the PCR vial was analyzed on $2 \%$ agarose gel electrophoresis and visualized under UV light by staining with ethidium bromide.

Specificity and sensitivity of PCR for HPV detection. The specificity of the PCR assay was tested using nucleic acids prepared from Penaeus monodon, WSSV (Wongteerasapaya et al. 1995a), YHV (Wongteerasupaya et al. 1995b), nuclear polyhedrosis virus (NPV) (obtained from the Rice Research Center, Kasetsart University, Thailand), Salmonella (obtained from National Institute of Health, Thailand), monodon baculovirus (MBV)-infected hepatopancreatic tissue (obtained from Charoen Pokaphan Shrimp Culture Research Center, Thailand) and IHHNV-infected tissue (provided by Prof. T. W. Flegel, Biotechnology, Mahidol University, Thailand). The nucleic acids were subjected to DNA amplification and the PCR products were analyzed by agarose gel electrophoresis as described above.

To test sensitivity, purified HPV genomic DNA was serially diluted from $10 \mathrm{ng}$ to $0.01 \mathrm{fg}$ (10-fold dilutions) and the diluted fractions were then used as DNA templates in PCR reactions. The PCR products $(15 \mu l)$ were analyzed by ethidium bromide stained agarose gel electrophoresis.

Detection of HPV from crude DNA templates. Hepatopancreatic tissue of juvenile shrimp of Penaeus monodon were used for preparation of crude DNA templates for HPV detection by PCR assay. These tissues (approximately $200 \mathrm{mg}$ ) were homogenized in a solution of $0.05 \mathrm{~N} \mathrm{NaOH}$ and $0.025 \%$ SDS in a $1.5 \mathrm{ml}$ tube. The suspension was then boiled for $5 \mathrm{~min}$, chilled on ice and centrifuged at $10000 \times g$ for $2 \mathrm{~min}$. Then, 1 to $5 \mu \mathrm{l}$ of the supernatant solution was used as the template addition for PCR reactions as described above.

\section{RESULTS}

\section{Histology and ultrastructure}

Of the 79 hepatopancreas samples prepared for normal histology, 24 samples (30.4\%) showed the presence of basophilic, intranuclear inclusions in hypertrophied nuclei, typical of HPV as described by Lightner (1996) (Fig. 1A). Many infected cells contained 2 or

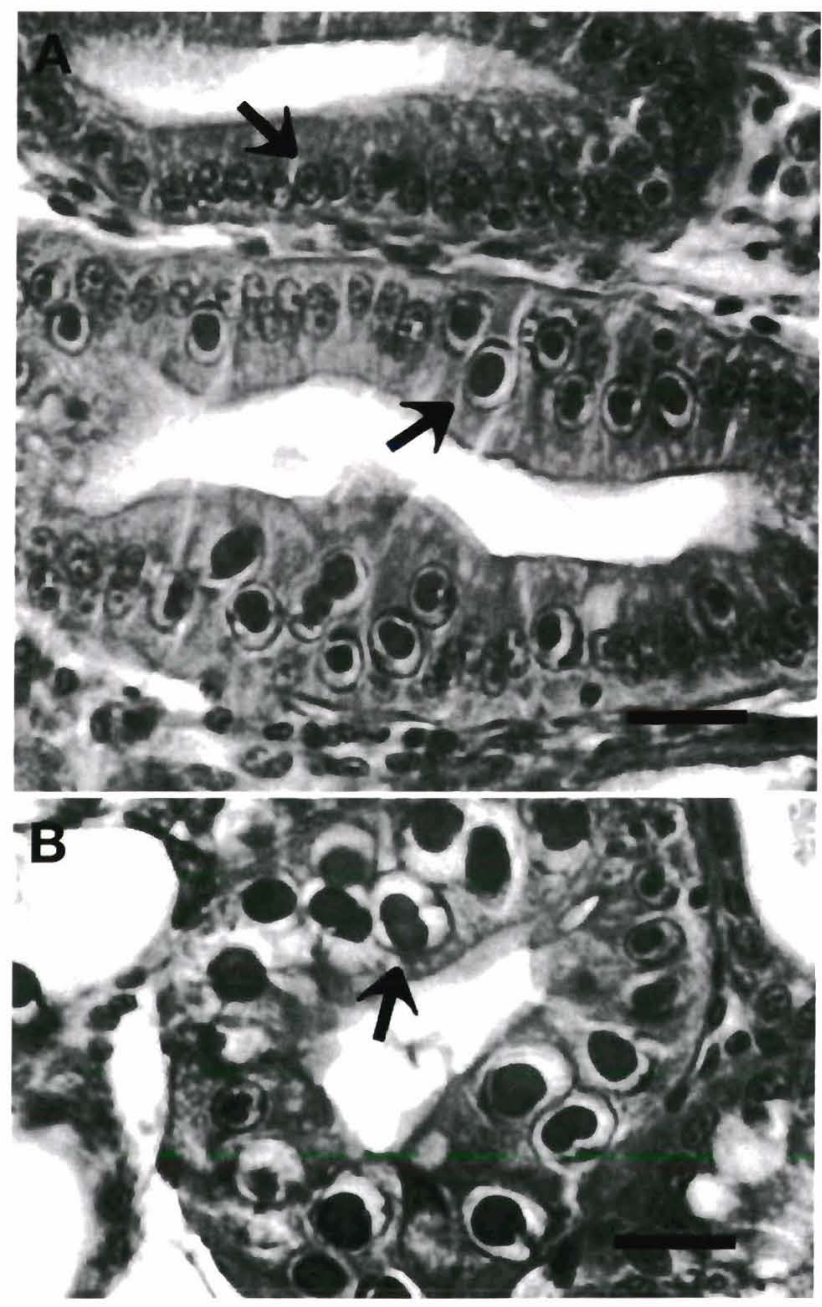

Fig. 1. Photomicrographs of HPV-infected hepatopancreatic tissue of Penaeus monodon stained with H\&E. The specimen photographed was drawn from the set used to purify HPV. (A) Uppermost arrow indicates a normal hepatopancreatic cell and lowermost arrow indicates a prominent, basophilic, intranuclear inclusion typical of HPV infection; (B) arrow shows an HPV-infected cell with 2 inclusions within the hypertrophied nucleus. Scale bars $=5 \mu \mathrm{m}$ 
more inclusions (Fig. 1B). TEM (Fig. 2) revealed that these inclusions comprised large arrays of unenveloped viral particles typical of those described for HPV in other penaeid shrimp (Lightner 1996). Based on the appearance of several electron micrographs, we consider that Fig. 2 shows 2 adjacent HPV inclusions cut at different angles at low (Fig. 2A) and high (Fig. 2B) magnification, although others may interpret the upper structure as a nucleolus.
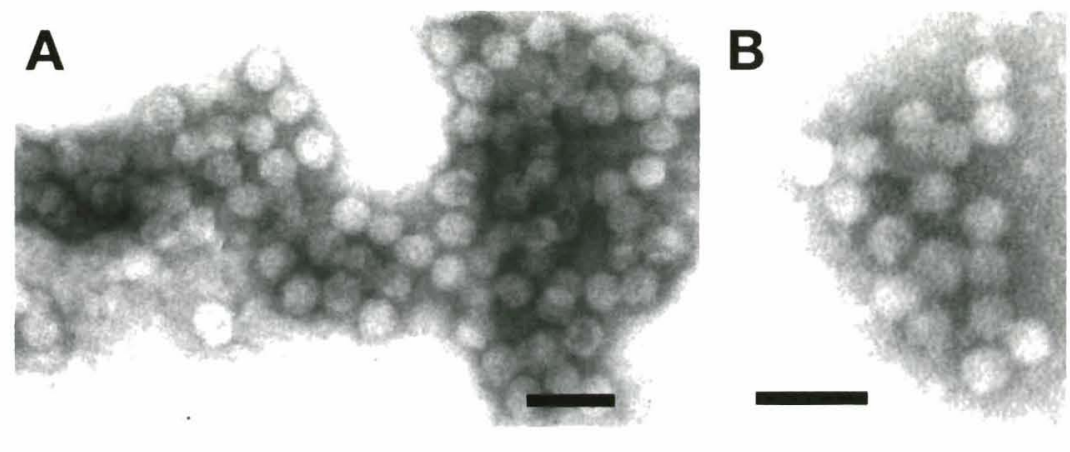

Fig. 3. Electron micrograph of negatively stained HPV virions purified by urografin gradient ultracentrifugation. Scale bars $=50 \mathrm{~nm}$
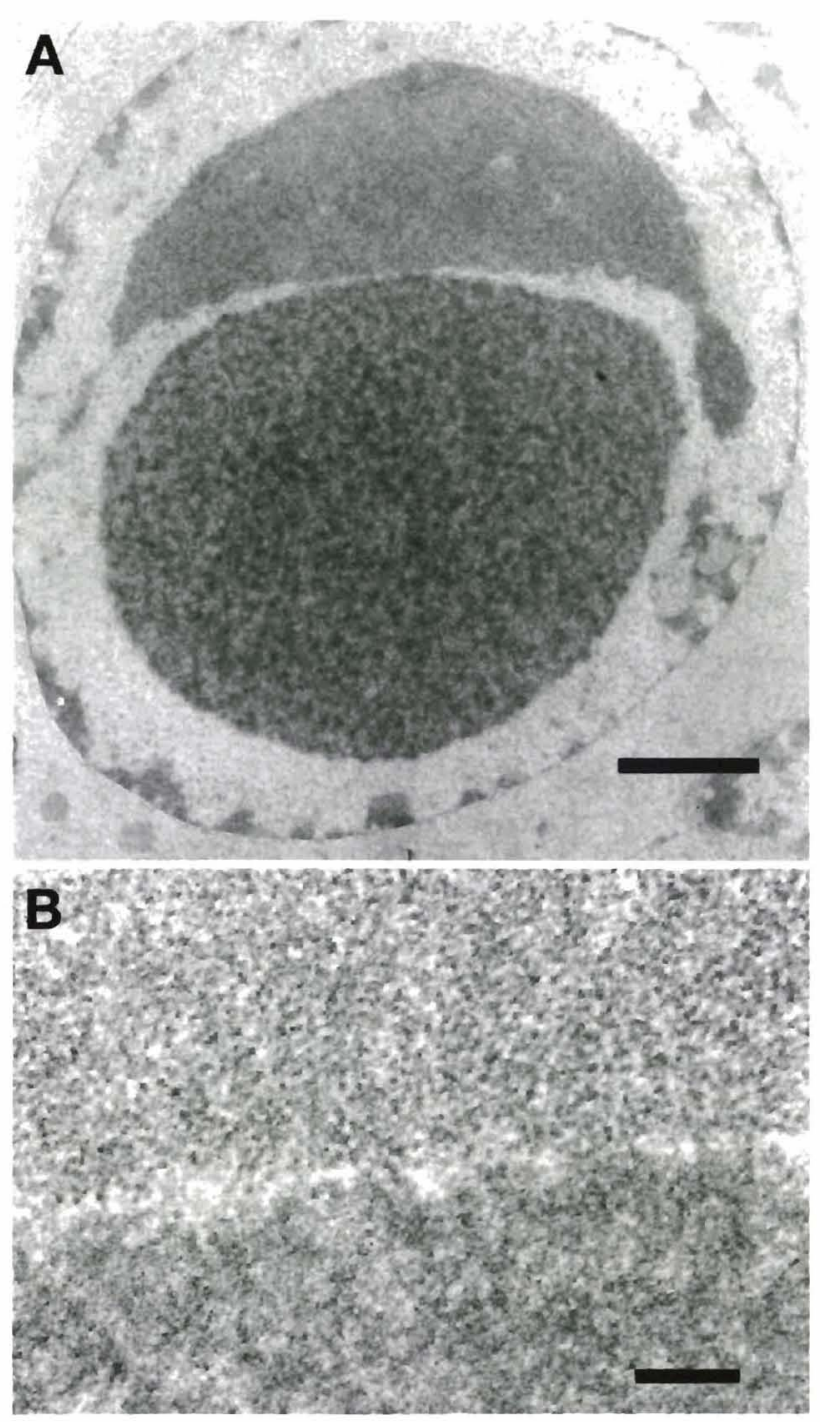

Fig. 2. Transmission electron micrograph of a thin section of hepatopancreatic tissue of Penaeus monodon infected with HPV. Two adjacent inclusions are shown in (A) low and (B) high magnification. The viral arrays were cut at different angles, such that viral outlines are more clearly visible in the upper inclusion. Scale bars: $(A)=2 \mu \mathrm{m}$; $(B)=0.2 \mu \mathrm{m}$

\section{Viral purification}

The crude viral precipitate from homogenized hepatopancreatic tissue gave a band at the 25 to $30 \%$ interval by urografin gradient ultracentrifugation. By TEM, this band contained the highest quantity virions. Intact virions were unenveloped and circular to hexagonal in shape with a diameter of 22 to $24 \mathrm{~nm}$ (Fig. 3).

\section{Nucleic acid extraction and characterization}

HPV nucleic acid was extracted from purified virions and analyzed by $0.7 \%$ agarose gel electrophoresis. The results are shown in Fig. $4 \mathrm{~A}$, where it can be seen that the extract contained 2 visible fragments. The most intense band was located at approximately $5.8 \mathrm{~kb}$, while a faint band was located at $4.2 \mathrm{~kb}$ (lane 2 ) relative to a dsDNA size marker. Both the 5.8 and $4.2 \mathrm{~kb}$ fragments were digested by DNase I (lane 3). When separately eluted from the gel, purified and divided into subfractions for enzyme treatment along with control DNA (i.e. M13 ssDNA and $\lambda$-Hind III dsDNA), it was found that the $5.8 \mathrm{~kb}$ fragment was sensitive to $S_{1}$ nuclease digestion whereas the $4.2 \mathrm{~kb}$ fragment was resistant (lanes 7 and 6, respectively). This suggested that the $5.8 \mathrm{~kb}$ DNA fragment comprised ssDNA while the 4.2 DNA fragment comprised dsDNA. Alkaline gel electrophoresis was carried out to evaluate the exact fragment size of the single-stranded DNA. The result (Fig. 4B, lane 3) was also $5.8 \mathrm{~kb}$. Although a strong $5.8 \mathrm{~kb}$ ssDNA band was obtained in all viral extraction attempts, the $4.2 \mathrm{~kb}$ dsDNA fragment was always weak. It could not be seen with lightly loaded gels (i.e. less than $100 \mathrm{ng}$ DNA).

\section{Cloning of HPV genomic DNA}

From 194 white colonies obtained after bacterial transformation, 16 clones gave strong hybridization 

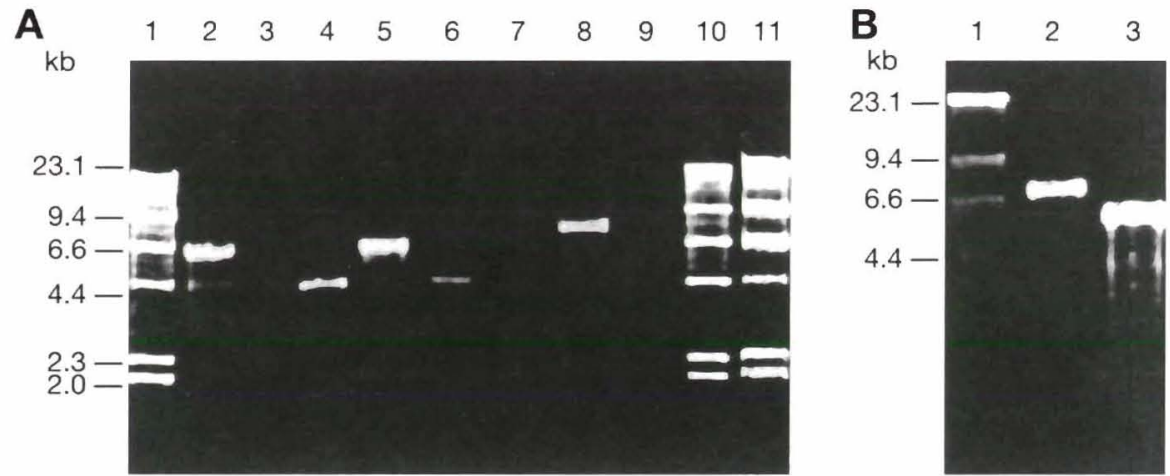

Fig. 4. Analysis and characterization of HPV DNA by agarose gel electrophoresis. (A) Normal agarose gel electrophoresis. In lane 2, the HPV nucleic acid extract can be seen to contain 1 dense band for a DNA fragments corresponding to $5.8 \mathrm{~kb}$ and a faint band corresponding to $4.2 \mathrm{~kb}$. Both fragments were degraded by DNase I (lane 3 ). These DNA bands were separately excised from a gel, eluted and purified (lanes 5 and 4, respectively). The preparations were then treated with nuclease $\mathrm{S}_{1}$ (lanes 6 and 7 ) together with a positive control sample of M13DNA ssDNA (lane 9), and negative control samples of undigested M13 DNA ssDNA (lane 8) and $S_{1}$ nuclease treated $\lambda$-Hind III DNA marker (lane 11). Lanes 1 and 10 comprised untreated $\lambda$-Hind III DNA marker. The $5.8 \mathrm{~kb}$ fragment and the control M13 DNA (lanes 7 and 9) were degraded by $\mathrm{S}_{1}$ nuclease while the $4.2 \mathrm{~kb}$ fragment (lane 6) and the $\lambda$-Hind III DNA marker (lane 11) were not. (B) Alkaline gel electrophoresis. The total DNA extract of HPV (lane 3) (cf. lane 2 in gel A) is compared with M13 ssDNA (lane 2) and $\lambda$-Hind III DNA marker (lane 1). The dense band of HPV DNA corresponds to approximately $5.8 \mathrm{~kb}$ of the marker

with digoxigenin-labeled HPV DNA by Southern blot hybridization assay, and they were selected for further study. The insert sizes for only 3 clones were larger than $1 \mathrm{~kb}$. One clone (pMUH659) was selected by dot blot hybridization because of its strong hybridization with HPV nucleic acid, but not with nucleic acid of other viruses, shrimp and bacteria.

\section{Southern blot hybridization of HPV genomic DNA}

HPV genomic DNA was electrophoretically analyzed on agarose gel and Southern transferred onto

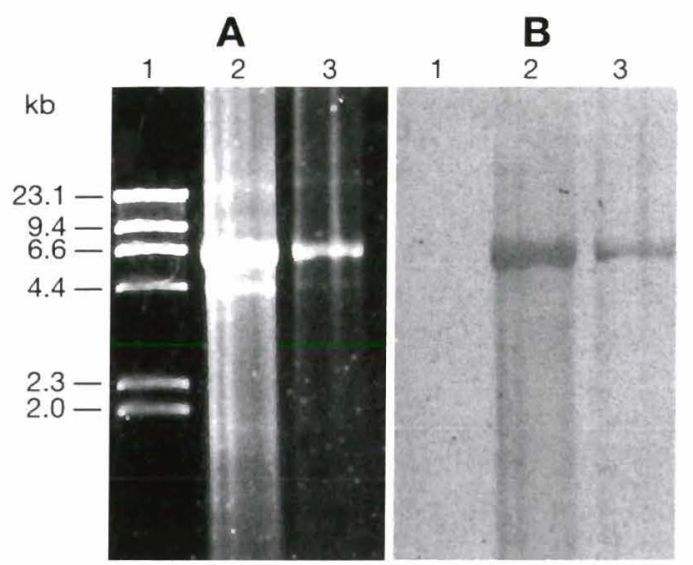

nylon membranes using 2 different methods, without (Fig. 5A,B) and with (Fig. 5C,D) alkali denaturation of DNA. The membranes were then hybridized with digoxigenin-labeled pMUH659 insert. The result without denaturation (Fig. 5A,B) showed that the probe hybridized strongly with the $5.8 \mathrm{~kb}$ fragment of HPV genomic DNA, suggesting that it comprised ssDNA. It did not hybridize with the $4.2 \mathrm{~kb}$ DNA fragment. The labeled commercial probe from HPV in HPV-chin (DiagXotics) also hybridized only with the $5.8 \mathrm{~kb}$ fragment of HPV-mon and at similar intensity (data not shown). Southern transfer of HPV-mon genomic DNA, with alkaline denaturation (Fig. 5C,D),

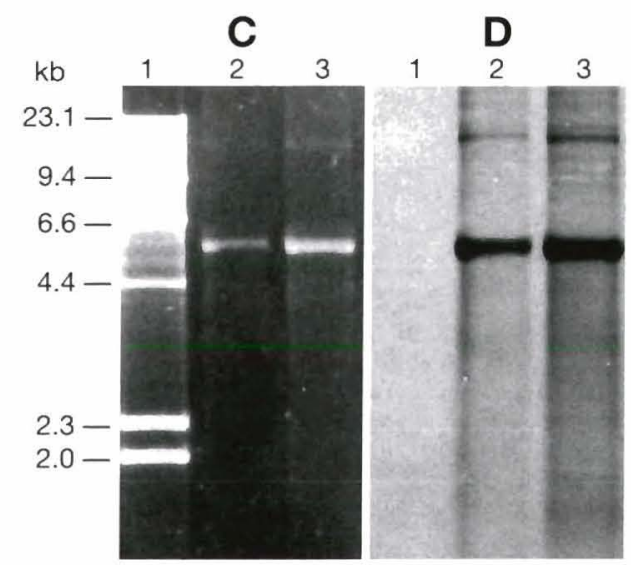

Fig. 5. Southern blot hybridization of HPV genomic DNA. (A) Ethidium bromide stained gel of HPV genomic DNA. Lane 1: $\lambda$-Hind III DNA size marker. Lanes 2 and 3: HPV genomic DNA 1 and $0.2 \mu \mathrm{g}$, respectively. (B) Southern transfer of DNA in (A) without alkaline denaturation and hybridization with the digoxigenin-labeled 659 bp probe. (C) Ethidium bromide stained gel of HPV genomic DNA. Lane 1: $\lambda$-Hind III DNA size marker. Lanes 2 and 3: HPV genomic DNA 0.1 and $0.2 \mu$ g, respectively. (D) Southern transfer of DNA in (C) with alkaline denaturation and hybridization with the probe. The probe hybridizes only with the upper band (i.e. $5.8 \mathrm{~kb}$ equivalent) and higher bands comprising double or partially double stranded complexes of the virual genome 
5. GCA CTT ATC ACT GTC TCT ACC CAA GTC ATG AGC TGT CTG AAA GCC TTG TAT ATA TGG CAA CCA GAC TTT GCT CAA GAA ATC CTC CTC CTT CAT GGT TAG CAT TTT CAC AGC TAT AGC ACT AAT CTT ATG ACA GAG CAA GGT ATT TAC AAA GTT CAC 3

Fig. 6. Nucleotide sequence of the $156 \mathrm{bp} \mathrm{PCR} \mathrm{product} \mathrm{ampli-}$ fied from HPV genomic DNA. Underlined bases represent the positions of primers $121 \mathrm{~F}$ and $276 \mathrm{R}$

also gave strong hybridization only with the $5.8 \mathrm{~kb}$ fragment, indicating that the $4.2 \mathrm{~kb}$ fragment was not a dsDNA construct related to the $5.8 \mathrm{~kb}$ fragment. However, the probe also hybridized with bands above the $5.8 \mathrm{~kb}$ fragment only in the alkaline denatured blot. Since denaturation was necessary for hybridization to take place, it was concluded that these bands represented double stranded DNA complexes of the viral genome.

\section{Sequence analysis and primer designation}

The nucleotide sequence of pMUH659 was determined using an automated sequencer. The insert size was 659 bp. From the nucleotide sequence data, 5 Sau 3AI sites were found, suggesting that ligation of Sau 3AI-digested HPV fragments had occurred during cloning. Therefore, primers were designed from the first $278 \mathrm{bp}$ of the sequence only. The designed primer set $(121 \mathrm{~F}$ and $276 \mathrm{R})$ amplified a 156 bp DNA fragment from HPV genomic DNA. The G/C content of the forward primer (121F) was $45 \%$ while that of the reverse primer (276R) was $33 \%$. The melting temperatures (Tm) for the primers were 58 and $56^{\circ} \mathrm{C}$, respectively. The nucleotide sequence of the amplified DNA fragment (156 bp), including the primer sequences, is shown in Fig. 6.
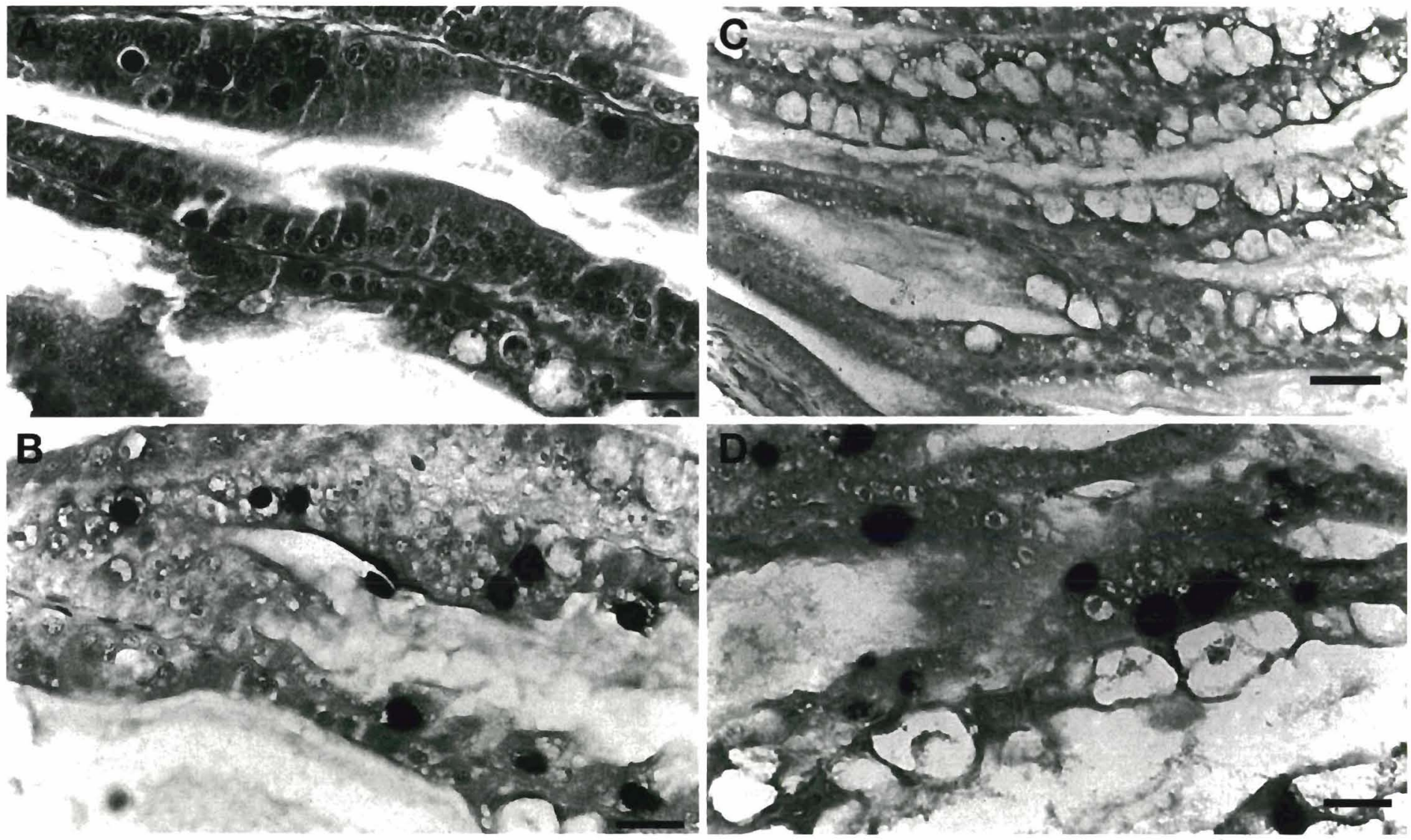

Fig. 7. H\&E staining and in situ hybridization of HPV-infected hepatopancreatic tissue. (A) and (B) show adjacent sections of tissue from Penaeus monodon stained by H\&E and by in situ hybridization using a digoxigenin-labeled 156 bp DNA probe (HPV-mon probe). (Scale bars $=5 \mu \mathrm{m}$ ). (A) H\&E stained section showing prominent hypertrophied nuclei typical of HPV infection. (B) Dark stained nuclei and intranuclear inclusions indicate a positive in situ DNA hybridization reaction with the probe for HPVinfected nuclei similar to those in the H\&E section. (C) A negative control in situ hybridization reaction in a section of normal P. monodon hepatopancreatic tissue not infected with HPV. (D) A positive in situ hybridization reaction using HPV-mon probe with hepatopancreatic tissue of $P$. chinensis infected with HPV-chin (control slide provided with DiagXotics reagents) 


\section{In situ hybridization}

Adjacent sections of HPV-infected hepatopancreatic tissue of Penaeus monodon (Fig. 7) were stained with H\&E (Fig. 7A) and tested by in situ hybridization with the digoxiginin-labeled 156 bp probe (Fig. 7B). A strong hybridization signal was obtained with HPVinfected tissue but no hybridization signal was observed from normal shrimp DNA (Fig. 7C). This probe also reacted strongly with an HPV-chin-infected hepatopancreatic tissue section supplied as a control for the DiagXotics HPV-chin probe reagent (Fig. 7D).

\section{Specificity and sensitivity of PCR detection}

The specificity of the PCR primers was demonstrated using nucleic acid templates of HPV-mon (50 fg), WSSV (10 ng), YHV (10 ng), NPV (10 ng), Salmonella (100 ng), shrimp (100 ng), MBV (infected hepatopancreatic tissue extract) and IHHNV (infected cephalothoracic tissue extract). A single amplicon of $156 \mathrm{bp}$ was observed only in reactions using HPV DNA as the template. No amplicons were seen with the other DNA templates employed (Fig. 8). To test for sensitivity, purified HPV DNA was used as a template for PCR amplification (40 cycles) at various serial dilutions ranging from $10 \mathrm{ng}$ to $0.01 \mathrm{fg}$. The results (Fig. 9) showed that the lowest amount of purified HPV genomic DNA detected was $1 \mathrm{fg}$, which corresponded to approximately 300 viral genomes.

\section{Detection of HPV in naturally infected tissues}

Crude DNA extracts prepared from HPV-infected hepatopancreatic tissue of juvenile shrimp of Penaeus monodon were used as templates in PCR assays. The expected $156 \mathrm{bp}$ amplicon was obtained with extracts from shrimp infected with HPV as determined by H\&E stained sections, but not from normal shrimp or shrimp infected with WSSV and YHV (Fig. 10). Strong Southern blot hybridization of amplicons with the digoxigenin-labeled 659 bp HPV genomic DNA fragment confirmed that they contained complementary sequences (data not shown).

\section{DISCUSSION}

The Thai isolate of HPV from Penaeus monodon (HPV-mon) is the third shrimp parvovirus to be characterized at the molecular level. The other 2 are HPV from P. chinensis (HPV-chin) of Korea (Bonami et al. 1995, Mari et al. 1995) and IHHNV from P. stylirostris of the

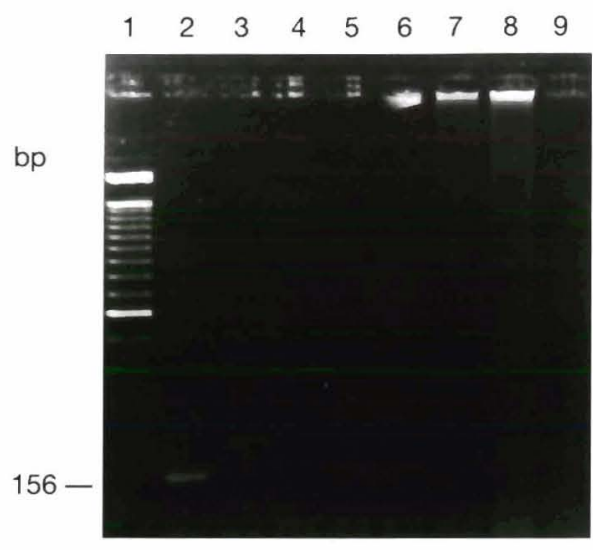

Fig. 8. Specificity of PCR assay. Ethidium bromide-stained gel of PCR products amplified from purified HPV genomic DNA $50 \mathrm{fg}$ (lane 2), YHV RNA $10 \mathrm{ng}$ (lane 3), WSSV DNA $10 \mathrm{ng}$ (lane 4), NPV DNA 10 ng (lane 5), Salmonella DNA 100 ng (lane 6), shrimp DNA 100 ng (lane 7), MBV-infected cephalothoracic tissue (lane 8) and IHHNV-infected hepatopancreatic tissue (lane 9). Lane 1: 100 bp DNA ladder marker. An amplification product was obtained only with HPV DNA. Primer dimers appear at the bottom of the gel in some lanes

Americas (Mari et al. 1993a). HPV-mon resembles HPV-chin in histopathology at the level of the light and electron microscopes $(75000 \times)$ and it is also similar in size and shape by negative staining for TEM. In addition, the commercial digoxigenin-labeled probe derived from HPV-chin hybridized to HPV-mon DNA in both Southern blot and in situ assays (data not shown). This indicated that HPV-chin was more closely related to HPV-mon than to the HPV reported from Macrobrachium rosenbergii in Malaysia (Lightner et al. 1994), which did not cross-react with the HPV-chin probe.

At the molecular level, however, HPV-mon differed substantially from HPV-chin. HPV-mon nucleic acid

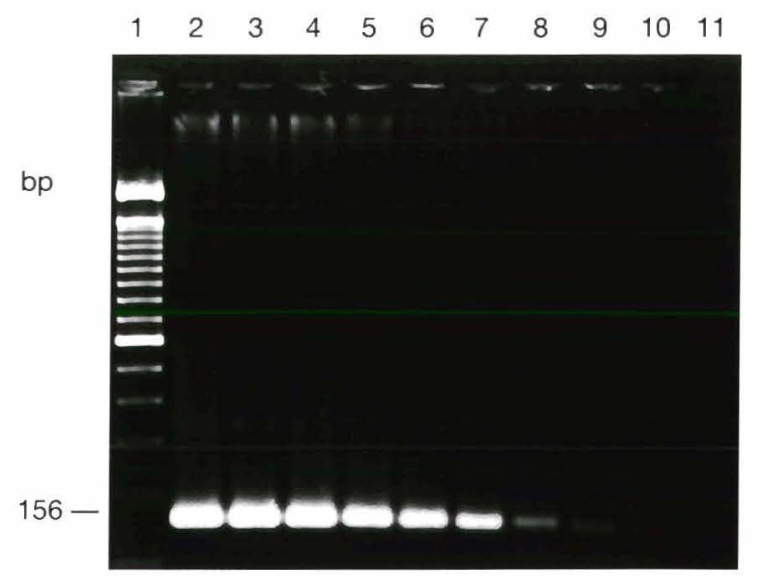

Fig. 9. Sensitivity of PCR assay. Ethidium bromide-stained gel of PCR products amplified from 1/10 serially diluted, purified HPV DNA. Lanes 2-11: HPV genomic DNA from $10 \mathrm{ng}$ to $0.01 \mathrm{fg}$, respectively. Lane 1: $100 \mathrm{bp}$ DNA ladder marker. Primer dimers at the bottom of the gel were cut from the photograph 


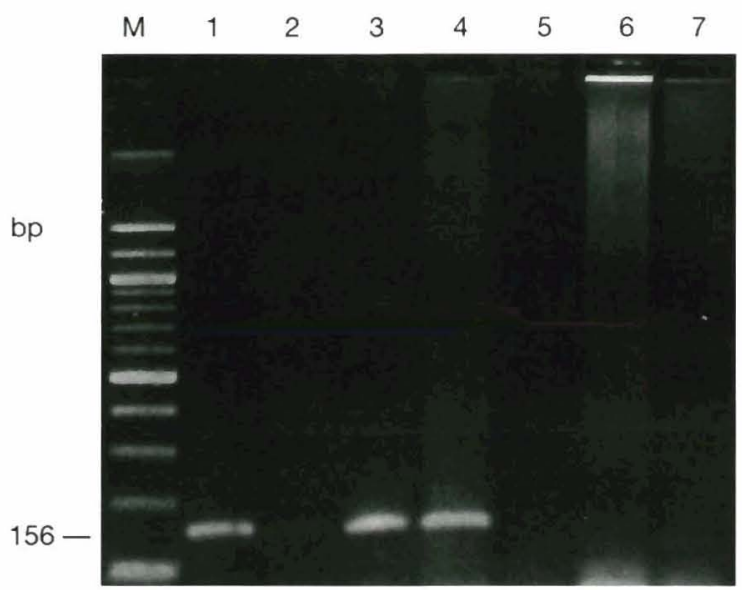

Fig. 10. PCR assay for detection of HPV infection in naturally infected Penaeus monodon. Hepatopancreas of $P$. monodon collected from field were homogenized in lysis buffer and subjected to PCR amplification for 40 cycles. Lane M: $100 \mathrm{bp}$ ladder; lane 1: purified HPV DNA (1 pg); lane 2-4: HPVinfected hepatopancreatic tissue (examined by H\&E staining); lane 5: healthy shrimp tissue; lane 6-7: gill of $P$. monodon infected with YHV and WSSV, respectively. Primer dimers can be seen at the bottom of the gel for lanes 6 and 7

extracts gave 2 bands of approximately 4.2 and $5.8 \mathrm{~kb}$, relative to a dsDNA standard on agarose gels. By enzyme assays, the major $5.8 \mathrm{~kb}$ band was found to comprise ssDNA (i.e. the viral genome) whereas the faster running $4.2 \mathrm{~kb}$ fragment comprised dsDNA. This contrasted with HPV-chin, which gave rise to 2 nucleic acid bands of 4 to 4.3 and $5 \mathrm{~kb}$. The ssDNA (i.e. the major band corresponding to the viral genome) comprised the faster running fragment ( 4 to $4.3 \mathrm{~kb}$ ) and the dsDNA the slower $5 \mathrm{~kb}$ fragment (Bonami et al. 1995). Clearly, the ssDNA genomes of these 2 viral strains differ by approximately $1 \mathrm{~kb}$ in size. A more detailed comparison of the genomic DNA of these viruses is needed to determine their interrelationship.

The dsDNA bands obtained for the 2 viruses differ not only in size, but also in nature. That from HPV-chin was suggested to consist of viral, doublestranded genomic DNA (Bonami et al. 1995) while that found here was clearly not of HPV-mon origin. Nor could its origin be determined with the tests used. However, Southen blot hybridization of alkaline denatured DNA from HPV-mon did reveal the presence of double-stranded complexes above $5.8 \mathrm{~kb}$ in the gel. These probably consisted of dsDNA complexes that arose from inter-strand hybridization of the palindromic DNA sequences found in the 'hairpins' at the ends of genomic ssDNA in the parvoviruses (Siegl 1990).

With respect to the $4.2 \mathrm{~kb}$ dsDNA found in this study, it might be argued that our isolated HPV-mon was contaminated with other viruses such as MBV and IHHNV, since they are commonly found in Thailand and because the shrimp used in this study came from the field. However, the viral particles obtained from urografin gradient ultracentrifugation showed the external morphological characteristic of parvoviruses, and no MBV virions were seen. Further, the extracted DNA was smaller than that previously reported from MBV (Mari et al. 1993b). On the other hand, IHHNV is also a parvovirus of size and morphology similar to HPV and would probably not be distinguishible from it by TEM. However, the commercially available IHHNV probe (DiagXotics) did not hybridize with total HPVmon DNA, even though it did give a positive in situ hybridization reaction with the IHHNV-infected Thai Penaeus monodon used here to test specificity of the HPV-mon PCR primers (Flegel unpubl.). These results suggested that the $4.2 \mathrm{~kb}$ fragment did not consist of IHHNV DNA that contaminated the HPV-mon DNA preparations. Nor did this dsDNA react with any of our HPV probes. Therefore, its origin remains unknown.

Our developed PCR assay provides a specific and sensitive detection of at least $1 \mathrm{fg}$ purified HPV DNA and it could be used with crude DNA templates simply prepared from shrimp tissue, including hepatopancreatic tissue or whole post-larvae. If the PCR assay could be further developed for screening shrimp feces, it might provide an easy, non-destructive way of screening broodstock and pond-reared shrimp. The PCRbased assay could also be convenient as a sensitive diagnostic tool for detection of HPV in asymptomatic or histologically negative carriers. This might be difficult or impossible by other methods. For example, in surveys of broodstock specimens of Penaeus monodon in Thailand (Flegel et al. 1992a, 1997), histological evidence of HPV infection was not found. Nor, to our knowledge, has HPV ever been reported in hatcheryreared larvae in Thailand or elsewhere. On the other hand, it has been reported from post-larvae in outdoor nurseries (Flegel et al. 1995) and from shrimp in growout ponds (Lightner 1996, Flegel et al. 1999). This information suggests that the source of HPV infections may be an unknown carrier present in nurseries and ponds. The PCR assay should be useful for screening potential carriers, which might then be excluded from the culture system.

For field applications where many samples must be processed and analyzed, the PCR-ELISA assay technique might be applied as an alternative method in order to avoid electrophoretic analysis of PCR products. These techniques are available commercially in comb or microtitre plate format (Boehringer Mannheim). In the future, the developed probe might be applied without PCR amplification, if a recently published visual technique for hybridization using goldlabeled DNA eventually allows for practical pond-side assays (Elghanian et al. 1997). 
Acknowledgements. The authors thank the National Center for Genetic Engineering and Biotechnology of Thailand and the Thailand Research Fund for support to carry out this work. Thanks also to Surapon Khongtim and Surayut Thaikua for technical assistance in preparation of tissue sections and slides.

\section{LITERATURE CITED}

Bell TA, Lightner DV (1988) A handbook of normal penaeid shrimp histology. World Aquaculture Society, Baton Rouge, LA

Bonami JR, Trumper B, Mari J, Brehelin M, Lightner DV (1990) Purification and characterization of the infectious hypodermal and haematopoietic necrosis virus of penaeid shrimps. J Gen Virol 71:2657-2664

Bonami JR, Mari J, Poulos BT, Lightner DV (1995) Characterization of hepatopancreatic parvo-like virus, a second unusual parvovirus pathogenic for penaeid shrimp. J Gen Virol 76:813-817

Elghanian R, Storhoff JJ, Mucic RC, Letsinger RL, Mirkin CA (1997) Selective colorimetric detection of polynucleotides based on the distance-dependent optical properties of gold nanoparticles. Science 277:1078-1081

Fegan DF, Flegel TW, Sriurairatana S, Waiyakruttha M (1991) The occurrence, development and histopathology of monodon baculovirus in Penaeus monodon in southern Thailand. Aquaculture 96:205-217

Flegel TW (1997) Special topic review: major viral diseases of the black tiger prawn (Penaeus monodon) in Thailand. World J Microbiol Biotechnol 13:433-442

Flegel TW, Sriurairatana S (1993) Black tiger prawn diseases in Thailand. In: Akiyama DM (ed) Tech Bull American Soybean Assoc, Singapore AQ39/1993(3), Sect B, p 1-30

Flegel TW, Sriurairatana S (1994) Shrimp health management: an environmental approach. In: Subasinghe RP, Shariff $M$ (eds) Diseases in aquaculture: the current issues. Malaysian Fisheries Society Publication No. 8, Faculty of Fisheries and Marine Science, University Pertanian Malaysia, Serdang, p 1-48

Flegel TW, Fegan DF, Kongsom S, Vuthikornudomkit S, Sriurairatana $\mathrm{S}$, Boonyaratpalin $\mathrm{S}$, Chantanachookhin $\mathrm{C}_{\text {, }}$ Vickers JE, Macdonald OD (1992a) Occurrence, diagnosis and treatment of shrimp diseases in Thailand. In: Fulks W, Main KL (eds) Diseases of cultured penaeid shrimp in Asia and the United States. The Oceanic Institute, Honolulu, p 57-112

Flegel TW, Fegan DF, Guerin M, Boonyaratpalin S, Sriurairatana S (1992b) High mortality of black tiger prawns from cotton shrimp disease in Thailand. In: Shariff M, Subasinghe RP, Authur JR (eds) Diseases in Asian aquaculture. I. Fish Health Section, Asian Fisheries Society, Manila, p 181-197

Flegel TW, Fegan DF, Sriurairatana S (1995) Environmental control of infectious shrimp diseases in Thailand. In: Shariff M, Authur JR, Subasinghe RP (eds) Diseases in Asian aquaculture. II. Fish Health Section, Asian Fisheries Society, Manila, p 65-79

Flegel TW, Thamavit V, Pasharawipas T, Alday-Sanz V (1999) Statistical correlation between severity of hepatopancreatic parvovirus (HPV) infection and stunting of farmed black tiger shrimp (Penaeus monodon). Aquaculture 174: $197-206$

Kanchanaphum P, Wongteerasupaya C, Sitidilokratana N,
Boonsaeng V, Panyim S, Tassanakajon A, Withyachumnarnkul B, Flegel TW (1998) Experimental transmission of white-spot syndrome virus (WSSV) from crabs to shrimp (Penaeus monodon). Dis Aquat Org 34:1-7

Kimura T, Yamano K, Nakano H, Momoyama K, Hiraoka M, Inouye K (1996) Detection of penaeid rod-shaped DNA virus (Prdv) by PCR. Fish Pathol 31:93-98

Lightner DV (1996) A handbook of pathology and diagnostic procedures for diseases of penaeid shrimp. World Aquaculture Society, Baton Rouge, LA

Lightner DV, Redman RM, Moore DW, Park MA (1993) Development and application of a simple and rapid diagnostic method to studies on hepatopancreatic parvovirus of penaeid shrimp. Aquaculture 116:15-23

Lightner DV, Redman RM, Poulos BT, Mari JL, Bonami JR, Shariff M (1994) Distinction of HPV-type virus in Penaeus chinensis and Macrobrachium rosenbergii using a DNA probe. Asian Fish Sci 7:267-272

Lo CF, Leu JH, Ho CH, Chen $\mathrm{CH}$, Peng SE, Chen YT, Chou $\mathrm{CM}$, Yen PY, Huang CJ, Chou HY, Wang $\mathrm{CH}_{\text {, Kou } \mathrm{GH}}$ (1996b) Detection of baculovirus associated with white spot syndrome (WSBV) in penaeid shrimps using polymerase chain reaction. Dis Aquat Org 25:133-141

Maniatis T, Fritsch EF, Sambrook J (1982) Molecular cloning A laboratory manual. Cold Spring Harbor Laboratory, Cold Spring Harbor, NY

Mari J, Bonami JR, Lightner DV (1993a) Partial cloning of the genome of infectious hypodermal and hematopoietic necrosis virus, an unusual parvovirus pathogenic for penaeid shrimps; diagnosis of the disease using a specific probe. J Gen Virol 74:2637-2643

Mari J, Bonami JB, Polous B, Lightner DV (1993b) Preliminary characterization and partial cloning of the genome of a baculovirus from Penaeus monodon ( $\mathrm{PmSNPV}=\mathrm{MBV})$. Dis Aquat Org 16:207-215

Mari J, Lightner DV, Poulos BT, Bonami JR (1995) Partial cloning of the genome of an unusual shrimp parvovirus (HPV): use of gene probes in disease diagnosis. Dis Aquat Org 22:129-134

Siegl G (1990) Molecular biology and pathogenicity of human and animal parvoviruses. Behring Inst Mitt 85:6-13

Takahashi Y, Itami T, Maeda M, Suzuki N, Kasornchandra J, Supamattaya K, Khongpradit R, Boonyaratpalin S, Kondo M, Kawai K, Kusuda R, Hirono I, Aoki T (1996) Polymerase chain reaction (PCR) amplification of bacilliform virus (RV-Pj) DNA in Penaeus japonicus bate and systemic ectodermal and mesodermal baculovirus (SEMBV) DNA in Penaeus monodon fabricius. J Fish Dis 19:399-403

Wang SY, Hong C, Lotz JM (1996) Development of a PCR procedure for the detection of Baculovirus penaei in shrimp. Dis Aquat Org 25:123-131

Wongteerasupaya C, Vickers JE, Sriurairatana S, Nash GL, Akarajamorn A, Boonsaeng V, Panyim S, Tassanakajon A, Withyachumnarnkul B, Flegel TW (1995a) A non-occluded, systemic baculovirus that occurs in cells of ectodermal and mesodermal origin and caused high mortality in the black tiger prawn Penaeus monodon. Dis Aquat Org 21:69-76

Wongteerasupaya C, Sriurairatana S, Vicker JE, Akrajamorn A, Boonsaeng V, Panyim S, Tassanakajon A, Withyachumnarnkul B, Flegel TW (1995b) Yellow-head virus of Penaeus monodon is an RNA virus. Dis Aquat Org 22:45-50

Wongteerasupaya C, Tongcheua W, Boonsaeng V, Panyim S, Tassanakajon A, Withyachumnarnkul B, Flegel TW (1997) Detection of yellow-head virus (YHV) of Penaeus monodon by RT-PCR amplification. Dis Aquat Org 31:181-186 